\title{
The Effects of Visualization on Mathematics Achievement in Reference to Thesis Studies Conducted in Turkey: A Meta-Analysis
}

\author{
İlknur Gulsen Turgut ${ }^{1}$, Sedat Turgut ${ }^{2, *}$ \\ ${ }^{1}$ Department of Mathematics and Science Education, Faculty of Education, Dumlupinar University, Kutahya, Turkey \\ ${ }^{2}$ Department of Elementary and Early Childhood Education, Faculty of Education, Bartin University, Bartin, Turkey
}

Copyright $\bigcirc 2018$ by authors, all rights reserved. Authors agree that this article remains permanently open access under the terms of the Creative Commons Attribution License 4.0 International License

\begin{abstract}
In this study, it is aimed to determine the effect of visualization on mathematics achievement in the thesis studies conducted in Turkey. In this context, the findings obtained from individual studies are combined via meta-analysis. For this purpose, Council of Higher Education (CoHE) National Thesis Center database was thoroughly scanned by using keywords. A total of 35 thesis studies, 26 of which are master's thesis and 9 of which are doctoral dissertations were reached as a result of the scanning performed. 34 theses are included in the meta-analysis in line with their inclusion criteria and 42 effect sizes were calculated pertaining to these thesis. To examine the normal distribution of effect sizes and to perform other analyses, statistical programs of MetaWin and Comprehensive Meta-Analysis (CMA) were used respectively in the study. In the calculation of effect sizes, quantities of studies included in meta-analysis Hedges's $g$ was used and confidence level in calculations of effect sizes was taken as $95 \%$. The average effect size value calculated in accordance with random effect model was found as 0.811 with the standard error of 0.076 . Positivity of effect size shows that the implication effect is in favour of the experimental group. Basing on this, it can be said that visualization has a moderate effect on mathematics achievement.
\end{abstract}

Keywords Visualization, Mathematics, Achievement, Meta-Analysis

\section{Introduction}

There are a lot of researches and publications in numerous fields of expertise (psychology, engineering, arts, medicine, economics, chemistry etc.) regarding visualization [26]. Along with these fields, visualization is also seen in intensive language communication. Visual representations are used to fulfill the function of language in communication [43]. So the importance of visualization should not be ignored. Because it is found out that human beings are tend to trust visual information more than other forms of sensory information in many cases [55]. The reason why visual information convinces people more might be the role of eyesight in forming the basis of the biological and socio-cultural existence of human beings [6]. Therefore visual information and visualization are a part of human life and valued by humans.

Visualization is also utilized in mathematics as in many other fields of science. But the meaning of visualization in mathematics is different in comparison with other fields of science. Visualization is a reasoning activity in mathematics [26]. Information stated by a different representation in mathematics can also be expressed by a visual representation. This visual representation may facilitate the process of understanding in mathematics. For example utilization of pictorial presentations might help to deduce simply and directly [41]. In a more general saying all kinds of relationships of a mathematical object can be apprehended easier and more rapidly due to visualization [22].

Visualization has a key role for mathematicians and they have been using visualization for a long time in their studies [48]. Actually, visual presentations in mathematics are as old as mathematics itself [52, 57]. Rival [52] mentioned that geometry and other branches of mathematics were predominantly based on images in the past. Even numerous important developments based on visuals left their marks on the history of mathematics [13]. Consequently, it can be stated that mathematics and visualization also were one within the other more in the past.

The basic issue in the mathematics instruction has always been comprehension [23]. Comprehension is 
possible if mathematical discovery is made properly [61]. In this case, the importance of facilitating mathematical discovery comes forward. Visual presentations convey the information systematically and especially by using interesting and effective ways and, visualization serves an important purpose like facilitating learning and teaching mathematics [61]. Especially the developments in computer technology make it possible for visual presentations to have a wide scale of diversity [46]. Hence, it can be said that it is necessary to include visualization in mathematics instruction to provide mathematical discovery and comprehension resulting from it.

Even though various terms (visual reasoning, spatial thinking, visual images, spatial images etc.) are used in the field of visualization, there is not a general acceptance of these terms [26]. Similarly, even though there are numerous concepts (spatial ability, spatial reasoning, spatial concepts, mental maps etc.) in the field, there is not a more general clear agreement in the field of spatial literature [45]. When the body of literature is checked, visualization and spatial thinking might seem as different terms but they have the same meaning and visualization is also expressed as visual thinking or visual imagery [26]. Visualization and spatial thinking are not discriminated and they are regarded as they have the same meaning in this study. However it is stated in the literature that concepts of spatial thinking and spatial ability have the same meaning $[66,67]$ or different meanings [67] and even spatial ability has a narrower meaning than spatial thinking [45]. Spatial visualization, on the other hand, is regarded either as a sub-component of spatial ability $[11,45,66]$ or used instead of spatial ability. Moreover, the concepts of spatial ability, spatial visualization, visual-spatial ability, and three-dimensional visualization are regarded as they have the same meaning in the body of literature [66]. It is obvious that there are numerous interrelated and interchangeable terms are used on the subject of visualization. Even though these terms are used differently at some points, they are all connected to visualization. Consequently, it turns up that some concepts are directly (visual thinking, visual imagery etc.) or indirectly (spatial thinking) used instead of visualization and indirectly as a sub-component (spatial visualization).

There are various definitions of visualization in literature. By considering these definitions and conceptual relationship mentioned up to now, it is tried to specify the criteria to be included in the study. According to Hershkowitz [30, p. 75], "Visualization generally refers to the ability to represent, transform, generate, communicate, document, and reflect information on visual." In that case, visual information is a requisite of visualization. At this point, knowledge of what could be regarded as visual information in mathematics, how to compose visual information and how to use it becomes important for a better understanding of visualization and forming the study. The visual information, which is used effectively for mathematical discovery and comprehension during the visualization process, is shaped mentally by using paper and pencil or by technology [70]; it is composed of visual designs such as figures, pictures, images or diagrams etc. [6, 9]. In other words, visual information can be created via mind, paper and pencil or technology and visual designs from which implications regarding mathematical information could be made constitute visual information. Visual presentations of mathematical problems, principles or concepts are used and produced during mathematical visualization process [70], problems are solved and characteristics are proved [26]. Accordingly, visual information can be used to comprehend and prove mathematical concepts and to solve problems. In visualization which is a type of reasoning in mathematics visual, spatial, mental or physical elements are used [26]. In general, dissertations investigating the effect of visualizing mathematical information via paper and pencil or technology by various visual designs (figures, graphics, pictures, images or diagrams etc.) on the mathematic achievement of students are examined in this study.

There are numerous thesis studies investigating the effect of visualization on mathematics achievement in Turkey. Different results have been obtained by these thesis studies. The relationship between visualization and mathematics achievement is examined for different factors (educational level, implemented technique of visualization, learning domain, implementation period and sample size) in these theses. More extensive evaluations can be done by combining these researches. The relationship between visualization and mathematics achievement and determination of the effects of different variables on achievement is important in terms of inspiring researchers and leading researches to be conducted in this field. At that point, the role of meta-analysis studies arises. By meta-analysis, results of similar studies done independently can be combined by statistical method and interpreted coherently [15]. Investigating the literature, there are not any meta-analysis studies examining the effect of visualization on mathematics achievement. In this study, it will be tried to statistically reveal the effects of visualization on mathematics achievement by meta-analysis from the point of various variables basing on thesis regarding visualization in mathematics instruction.

\section{Materials and Methods}

\subsection{Research Model}

The purpose of this study is reviewing the literature with regard to the effects of visualization in mathematics instruction. In this context, findings of individual studies are combined by meta-analysis. Thus, the effect sizes regarding the effects of using visualization on achievement are calculated and a general assessment is 
searched.

Meta-analysis is accepted as the analysis of the analyses. Meta-analysis enables the researchers to statistically analyze the results of individual analyses and combine the findings [25]. In other words, meta-analysis is a research method aiming to determine the relevant field of science by quantitatively combining the results of certain researches done in any field [54].

Meta-analysis is used to reduce the limitedness of individual studies. To do this, primarily all studies on a certain topic are collected. Then the results of these studies are synthesized by using statistical tools [24]. While synthesizing the studies through meta-analysis, the effect size is used to standardize the results and facilitate inter-study comparisons [42]. Effect size is a value reflecting the strength of the relationship between two variables [12]. In other words, it means the size of the relationship between variables. It can be thought that effect size is a common measure for the studies included in meta-analysis and the studies can be interpreted by using the same standard by this means. Based on the definitions, it can be said that the purpose of meta-analysis is to combine quantitative data obtained from individual studies and to reach a general conclusion regarding the related topic.

Meta-analysis has five steps [47]:

1) All possible studies regarding a certain topic are found,

2) Consistent criteria are developed to provide the selectivity of studies,

3) Information regarding the topic are extensively determined and recorded for each study,

4) The recorded data is analyzed,

5) A summary of conclusion based on the findings is drawn.

In this study, it is tried to determine the level of the effect of visualization on mathematics achievement by following the mentioned steps.

\subsection{Data Collection}

The research data was collected within January 2017. The data sources of the research were composed of master's thesis and doctoral dissertations performed in Turkey and examining the effect of visualization on mathematics achievement. As visualization techniques are used in mathematics instruction (computer-based, worksheets, paper folding etc.) Council of Higher Education (CoHE) National Thesis Center database was thoroughly scanned online by using keywords such as "mathematics instruction, achievement" in order not to miss relevant dissertations and 483 recorded theses were found. These theses were reviewed one-by-one and experimental studies investigating the effect of visualization on mathematics achievement were determined. Basing on the determined theses, the keywords were determined in terms of visualization. These keywords are "visualization, visual representation, computer, website, dynamic software, spatial visualization, spatial ability, spatial thinking, visual thinking, visual imagery, visual-spatial ability, three-dimensional visualization, learning object, augmented reality, origami, Maple, GeoGebra, Cabri, Cabri 3D, Geometer's Sketchpad and Autograph". Then CoHE database was re-scanned. Additionally, since "Matlab, Mathematica, MuPad, MathAID, and Crocodile Mathematics" are dynamic software programs used in visualization, the names of these programs were scanned in CoHE database as keywords. At the end of these scannings, a total of 35 dissertations, 26 of which are master's thesis and 9 of which are doctoral dissertations, are reached. The theses that would be included in the meta-analysis were specified in line with the below criteria:

1) The thesis should be prepared between the years of 2003-2017.

2) The thesis should be either in Turkish or in English.

3) The thesis should be open to access in CoHE National Thesis Center database or could be accessed via Turkish Document Provision System (TUBESS).

4) The thesis should be related to preschool, elementary school, middle school, high school and university students in Turkey.

5) The thesis should have both experimental and control group and designed through pretest-posttest model.

6) Visualization techniques should be implemented to the experimental group and other instruction approaches should be implemented to the control group in the thesis.

7) The statistical values such as arithmetic means, standard deviation values or required statistical values (T-Test, analysis results of F-Test and pretest-posttest correlations etc.) to calculate effect size should be given in thesis.

8) Information regarding validity and reliability of assessment instruments used in thesis should be available.

One of the master's theses is not included in the analysis as it does not involve the required statistical values in accordance with specified criteria to calculate the effect size. As 4 achievement tests were implemented to the same experimental group in one of the doctoral dissertations, 4 effects sizes were calculated. In other words, this dissertation was evaluated as 4 different studies. In another doctoral dissertation the same achievement test was implemented to 2 different experimental groups and so 2 effect sizes were calculated. In other words, it was evaluated as 2 different studies. Also, 3 different achievement tests were implemented to the same experimental group in one of the master's thesis and 3 different effect sizes were calculated, this thesis was regarded as 3 different studies. In another master's thesis, 3 
different achievement tests were implemented in accordance with the grade levels and thereby 3 effect sizes were calculated. Therefore, this thesis was regarded as 3 different studies. In order to prevent confusion regarding this type of studies, letters "a, b, c, and d" were written next to the year of the study. At the end, 34 studies were included in the meta-analysis and 42 effect sizes were calculated.

\subsection{Data Coding}

A coding form was created regarding the inclusion criteria in order to be used at the phases of meta-analysis process. This form included the information of thesis number, name, author, publication year, type, educational level of sample, sample size, implemented visualization technique, learning domain where the implementation is done, implementation period, statistical information regarding experimental and control groups (sample size, arithmetic mean, standard deviation etc.), information regarding validity and reliability of utilized assessment instruments. The information about theses to be included in the meta-analysis on the forms was separately coded by two researchers. The researchers got together after coding, compared the forms and agreed on coding. By doing this, it was aimed to determine the accuracy of the studies to be included in meta-analysis and to include the data in analysis without any mistake.

\subsection{Data Analysis}

Effect size is used to standardize the results and facilitate inter-study comparisons in the meta-analysis [42]. There are two approaches for calculating effect size: fixed effect model and random effect model. In fixed effect model, it is assumed that effect sizes of the universes of researches in meta-analyses do not differ. Therefore effect sizes and standard deviations of the universes are accepted as zero [21]. In this context, each study has a real effect value [12]. In random effect model, on the other hand, it is assumed that effect sizes of meta-analyzed studies differ from 1 study to the other. Therefore, effect sizes and standard deviations of the universes are different from zero. In this context, effect value of each study might differ [21].

In order to select the model to be used in the meta-analysis, it is tested whether the effect sizes of the included studies have homogenous distributions or not. In order to do this, the results of Q-Statistic are checked. If effect sizes have homogenous distribution, fixed effect model should be used and if effect sizes have heterogeneous distribution, random effect model should be implemented [21]. Q-Statistics is used to test the null hypothesis which asserts that all studies included in meta-analysis share a common effect size by chi-square distribution. If the obtained $\mathrm{Q}$ value is lower than the corresponding value in chi-square $\left(\mathrm{X}^{2}\right)$ table in terms of significance level ( $\mathrm{p}$-value) and degree of freedom (df), homogeneity is obtained. However, if the studies to be included in the meta-analysis are obtained from unpublished articles, it is more reasonable to use random effect model [12]. Basing on this information, random effect model was used in this study.

In the study statistical program of MetaWin was used to examine normal distributions of effect sizes and Comprehensive Meta-Analysis (CMA) was used for the other analyses. To calculate the effect sizes of studies included in meta-analysis formats where mean $(\bar{X})$ and standard (SD) deviations and sample sizes (N) of experimental and control groups or formats, the necessary statistical values ( $\mathrm{p}$ value, $\mathrm{t}$ value etc.) can be entered via the interface provided by CMA program.

Publication bias is examined by using funnel plot and Rosenthal's safe $\mathrm{N}$ statistic in the study. If there is no publication bias, funnel plot shows that the effect sizes of included studies in meta-analysis are symmetrically distributed around the general effect size [12]. However asymmetrical distribution might be caused by various factors and also might express a real heterogeneity [60]. Therefore it might not be true to say that an asymmetrical distribution always results from publication bias. Rosenthal's N statistics (fail-safe N-FSN) might be defined as the number of studies to be added to analysis in order to reduce the effect calculated in meta-analysis to zero [12]. If $\mathrm{N}$ value increases, the reliability of the result of the study also increases [21]. Basing on Rosenthal's statistics Mullen, Muellerleile and Bryant [44] stated that if the value obtained from $\mathrm{N} /(5 \mathrm{k}+10)$ ( $\mathrm{k}$ is the number of studies included in meta-analysis) is higher than 1 , the result of meta-analysis would be sufficiently resistant for following studies.

Hedges's g was used in the study to calculate effect sizes of the included studies in meta-analysis and the reliability level in effect size calculations was taken as $95 \%$. The following criteria were taken into consideration to interpret the effect sizes obtained from meta-analysis: If effect size is between 0 and 0.20 , it has low effect level; if between 0.21 and 0.50 , it has a small level effect; if between 0.51 and 1.00, it has medium effect level and if more than 1 , the effect level is large [15, p. 521]. Educational level, implemented technique of visualization, learning domain, implementation period and sample size were determined as moderator variables in the study. Analog ANOVA test was utilized in the analysis of moderators.

\section{Findings}

Descriptive statistics of the theses conducted in Turkey in terms of the effect of visualization in mathematics instruction are given in Table 1. 
Table 1. Descriptive statistics of the theses investigating the effect of visualization on mathematics achievement

\begin{tabular}{|c|c|c|c|}
\hline & & Frequency & Percentage (\%) \\
\hline \multirow{2}{*}{ Study Type } & Master's Thesis & 25 & $73.53 \%$ \\
\hline & Doctoral Dissertation & 9 & $26.47 \%$ \\
\hline \multirow{12}{*}{ Study Year } & 2003 & 2 & $5.88 \%$ \\
\hline & 2006 & 1 & $2.94 \%$ \\
\hline & 2007 & 2 & $5.88 \%$ \\
\hline & 2008 & 1 & $2.94 \%$ \\
\hline & 2009 & 3 & $8.82 \%$ \\
\hline & 2010 & 1 & $2.94 \%$ \\
\hline & 2011 & 3 & $8.82 \%$ \\
\hline & 2012 & 6 & $17.65 \%$ \\
\hline & 2013 & 6 & $17.65 \%$ \\
\hline & 2014 & 4 & $11.76 \%$ \\
\hline & 2015 & 4 & $11.76 \%$ \\
\hline & 2016 & 1 & $2.94 \%$ \\
\hline \multirow{4}{*}{ Educational Level } & Elementary School & 1 & $2.94 \%$ \\
\hline & Middle School & 18 & $52.94 \%$ \\
\hline & High School & 6 & $17.65 \%$ \\
\hline & University & 9 & $26.47 \%$ \\
\hline \multirow{2}{*}{ Learning Domain } & Geometry & 21 & $61.76 \%$ \\
\hline & Mathematics & 13 & $38.24 \%$ \\
\hline \multirow{3}{*}{ Visualization Technique } & Computer-based & 27 & $79.41 \%$ \\
\hline & Worksheet & 3 & $8.82 \%$ \\
\hline & Paper folding (origami) & 4 & $11.76 \%$ \\
\hline \multirow{4}{*}{ Sample Size } & $1-20$ participants & - & - \\
\hline & 21-40 participants & 12 & $35.29 \%$ \\
\hline & 41-60 participants & 14 & $41.18 \%$ \\
\hline & 61 or more participants & 8 & $23.53 \%$ \\
\hline \multirow{8}{*}{ Implementation Period } & $1-5$ hours & 1 & $2.94 \%$ \\
\hline & 6-10 hours & 9 & $26.47 \%$ \\
\hline & 11-15 hours & 5 & $14.71 \%$ \\
\hline & 16-20 hours & 4 & $11.76 \%$ \\
\hline & $21-25$ hours & - & - \\
\hline & 26-30 hours & 6 & $17.65 \%$ \\
\hline & 31 hours and above & 1 & $2.94 \%$ \\
\hline & Unspecified & 8 & $23.53 \%$ \\
\hline Total & & 34 & 100 \\
\hline
\end{tabular}

As seen in Table 1, 25 of the theses $(73.53 \%)$ included in meta-analysis are master's thesis and $9(26.47 \%)$ are doctoral dissertations. The highest number of the theses were conducted in 2012 and 2013 (6 theses, 17.65\%) between the years of 2003 and 2017. When the educational level is considered, the highest number of the theses (18 theses, 52.94\%) was regarding middle schools and the lowest number of theses (1 thesis, 2.94\%) was done at primary schools. 21 of the theses $(61.76 \%)$ were about geometry and 13 of them (38.24\%) were about mathematics. Mostly computer-based visualization techniques are used in the theses (27 theses, 79.41\%). When the values are examined in terms of sample size, there is no thesis having a sample of 1-20 participants. 12 studies (35.29\%) used a sample of 21-40 participants, 14 studies (41.18\%) used a sample of 41-60 participants and 8 studies $(23.53 \%)$ used a sample of 61 participants and above. Visualization techniques in thesis are implemented between 6-10 hours at most ( 9 thesis, 26.47\%). There are 8 thesis studies $(23.53 \%)$ implementation periods of which are unspecified.

\subsection{Findings Regarding Effect of Visualization on Mathematics Achievement}

Normal distribution plot is examined for the convenience of combining the effect sizes of 34 studies included in meta-analysis. Normal distribution plot regarding the effect sizes in the studies is given in Figure 1. 


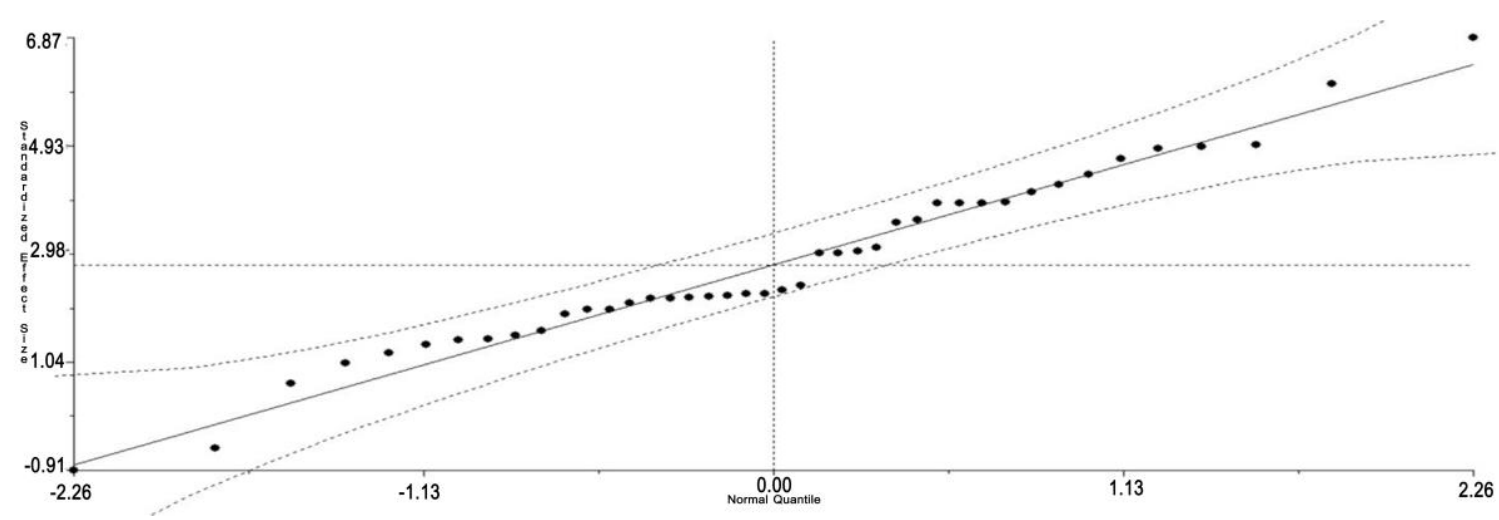

Figure 1. Normal distribution plot regarding effect sizes of studies included in meta-analysis

Funnel Plot of Standard Error by Hedges's $\mathbf{g}$

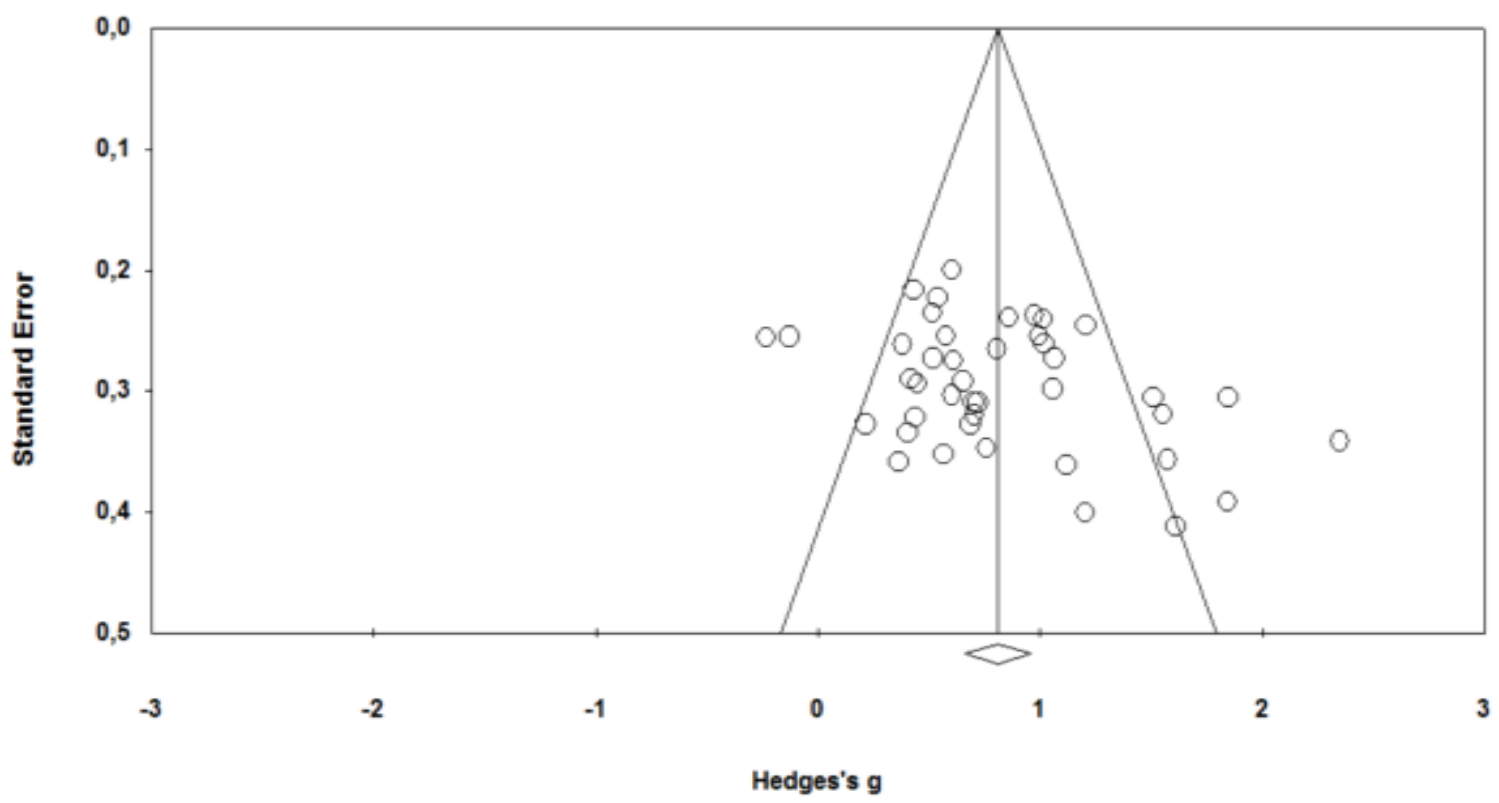

Figure 2. Funnel plot of the studies included in meta-analysis

When normal distribution plot in Figure 1 is examined, it is seen that the effects sizes of the studies included in meta-analysis are scattered around normal distribution line and between the confidence intervals indicated by dotted lines. Therefore it can be said that the effect sizes of the studies are normally distributed and could be statistically combined.

Funnel plot regarding the possibility of publication bias related to studies included in meta-analysis before the calculation of effect values with respect to determination of the effect of visualization on mathematics achievement is given in Figure 2.

When Figure 2 is examined, it is seen that the studies intensively gathered in the middle part of the funnel plot. The studies also show an almost symmetrical scatter on both sides of vertical line showing the combined effect size. This appearance points out a possibility of low level of publication bias. Therefore Rosenthal's safe $\mathrm{N}$ was also examined in addition to funnel plot. The information regarding Rosenthal's safe N statistic which was calculated with regard to meta-analysis about the effect of visualization on mathematics achievement is given in Table 2.

Table 2. Results of rosenthal's FSN statistic calculated with regard to meta-analysis examining the effect of visualization on mathematics achievement

\begin{tabular}{|c|c|}
\hline \multicolumn{2}{|c|}{ Bias State } \\
\hline Z value for monitored studies & 18.07074 \\
\hline P value for monitored studies & 0.00000 \\
\hline Alpha & 0.05 \\
\hline Direction & 2 \\
\hline Z value for Alpha & 1.95996 \\
\hline Number of monitored studies & 42 \\
\hline FSN & 3529 \\
\hline
\end{tabular}

As seen in Table 2, $\mathrm{N}$ value is found as 3529. In accordance with the formula of $\mathrm{N} /(5 \mathrm{k}+10)$ by Mullen et al. [44] related to publication bias basing on Rosenthal's proposition the result is $3529 /(5 * 42+10)=6.0409$. Therefore it can be said that the studies included in meta-analysis are resistant to publication bias. 
Homogeneity values, average effect sizes and confidence intervals of the studies in terms of fixed and random effect models to determine the model to be used to calculate effect sizes of studies included in meta-analysis are given in Table 3 .

When Table 3 is examined, homogeneity value of the studies included in meta-analysis through fixed effect model was calculated as $\mathrm{Q}=120.630$. It is determined in Chi Square table that the critical value of the degree of freedom 41 at $95 \%$ significance level is 56.942. According to these findings, Q value (120.630) is larger than the critical value (for $\mathrm{df}=41, x^{2}=56.942$ ) corresponding degree of freedom 41 in Chi Square table. Basing on this, it can be said that the studies included in meta-analysis have heterogeneous structure. Therefore, random effect model was used to calculate average effect sizes of studies included in meta-analysis. The average effect size calculated by using random effect model values was found as 0.811 by 0.076 standard error. The positive value of effect size proves that implication effect is in favour of experimental group. The calculated effect value (0.811) is close to strong level according to Cohen et al. [15]. Consequently, it can be said that visualization has a large positive effect on mathematics achievement.

The forest plot showing the distribution of the effect size values of primary studies constituted in terms of random effect model is given in Figure 3.

Table 3. Average effect sizes and lowest and highest values of confidence interval in terms of effect model

\begin{tabular}{|c|c|c|c|c|c|c|c|}
\hline \multirow{2}{*}{ Model } & \multirow{2}{*}{$\begin{array}{c}\text { Average Effect Size } \\
\text { Value (ES) }\end{array}$} & \multicolumn{2}{|c|}{ 95\% Confidence Interval of Effect Size } & \multirow{2}{*}{$\begin{array}{c}\text { Standard } \\
\text { Error (SE) }\end{array}$} & \multirow{2}{*}{$\begin{array}{l}\text { Homogeneity } \\
\text { Value (Q) }\end{array}$} & \multirow{2}{*}{$\begin{array}{l}\text { Degree of } \\
\text { Freedom }\end{array}$} & \multirow[b]{2}{*}{$\mathrm{p}$} \\
\hline & & Lower Limit & Upper Limit & & & & \\
\hline Fixed & 0.772 & 0.687 & 0.858 & 0.044 & \multirow{2}{*}{120.630} & \multirow{2}{*}{41} & \multirow{2}{*}{0.000} \\
\hline Random & 0.811 & 0.661 & 0.960 & 0.076 & & & \\
\hline
\end{tabular}

study name

\section{Ağaç 2009}

Akgül, 2014 a

Akgül, 2014 b

Akgül, 2014 c

Aksoy, 2007

Aktümen, 2007

Andiç 2012

Balci Seker, 2014

Basaran Simsek, 2012

Bulut, 2009

Çekmez, 2013 a

Çekmez, 2013 b

Çekmez, $2013 \mathrm{c}$

Çekmez, $2013 \mathrm{~d}$

Dagdelen, 2012

Doktoroğlu, 2013 a

Doktoroğlu, 2013 b

Doktoroğlu, $2013 \mathrm{C}$

Gübagci, 2009

Güburnu, 2013

Günes, 2016

Ibili, 2013 a

Ibili, 2013 b

Ipek, 2003

Kabaka, 2006

Kalay, 2015

Kan, 2014

Karaaslan, 2013

Konyalioglu, 2003

Küslü, 2015

Önür, 2008

Özçakir Sümen, 2013

Özçelik, 2014

Samur, 2015

Simsek, 2012

Takicak, 2012

Tayan, 2011

Tekin, 2010

Topaloglu, 2011

Tural Sönmez, 2012

Yücesan, 2011

Zengin, 2015

\begin{tabular}{|c|c|c|c|c|c|c|}
\hline & & atistics fo & acr & tay & & \\
\hline $\begin{array}{l}\text { Hedges's } \\
\text { g }\end{array}$ & $\begin{array}{l}\text { Standard } \\
\text { error }\end{array}$ & Variance & $\begin{array}{l}\text { Lower } \\
\text { limit }\end{array}$ & $\begin{array}{l}\text { Upper } \\
\text { limit }\end{array}$ & Z-Value & $\mathrm{p}-\mathrm{Ve}_{\mathrm{c}}$ \\
\hline 0.438 & 0.322 & 0.104 & -0.194 & 1.069 & 1.359 & \\
\hline 1.610 & 0.412 & 0.169 & 0.803 & 2.416 & 3.911 & \\
\hline 1.201 & 0.401 & 0.160 & 0.416 & 1.986 & 2.999 & \\
\hline 0.688 & 0.327 & 0.107 & 0.047 & 1.330 & 2.102 & \\
\hline 0.720 & 0.309 & 0.096 & 0.114 & 1.327 & 2.328 & \\
\hline 0.416 & 0.290 & 0.084 & 0.152 & 0.985 & 1.436 & \\
\hline 1.119 & 0.361 & 0.131 & 0.410 & 1.827 & 3.096 & \\
\hline 1.553 & 0.319 & 0.102 & 0.928 & 2.177 & 4.871 & \\
\hline 0.759 & 0.347 & 0.121 & 0.078 & 1.440 & 2.185 & \\
\hline 0.700 & 0.309 & 0.095 & 0.095 & 1.305 & 2.266 & \\
\hline 0.539 & 0.223 & 0.050 & 0.102 & 0.976 & 2.420 & \\
\hline 1.207 & 0.246 & 0.060 & 0.725 & 1.688 & 4.908 & \\
\hline 1.016 & 0.240 & 0.058 & 0.545 & 1.486 & 4.229 & \\
\hline 0.973 & 0.237 & 0.056 & 0.508 & 1.438 & 4.098 & \\
\hline 0.704 & 0.320 & 0.102 & 0.077 & 1.331 & 2.202 & \\
\hline-0.232 & 0.256 & 0.065 & -0.733 & 0.269 & -0.908 & \\
\hline-0.128 & 0.255 & 0.065 & -0.628 & 0.372 & -0.502 & \\
\hline 0.804 & 0.265 & 0.070 & 0.284 & 1.324 & 3.031 & \\
\hline 0.603 & 0.303 & 0.092 & 0.008 & 1.197 & 1.988 & \\
\hline 0.566 & 0.352 & 0.124 & -0.123 & 1.256 & 1.610 & \\
\hline 1.846 & 0.306 & 0.093 & 1.248 & 2.445 & 6.043 & \\
\hline 0.518 & 0.273 & 0.075 & -0.017 & 1.053 & 1.898 & \\
\hline 0.446 & 0.294 & 0.088 & 0.129 & 1.021 & 1.519 & \\
\hline 0.513 & 0.235 & 0.055 & 0.051 & 0.974 & 2.178 & \\
\hline 0.363 & 0.358 & 0.128 & -0.339 & 1.065 & 1.013 & \\
\hline 0.431 & 0.216 & 0.047 & 0.007 & 0.855 & 1.990 & \\
\hline 0.993 & 0.254 & 0.065 & 0.494 & 1.492 & 3.903 & \\
\hline 0.216 & 0.327 & 0.107 & -0.426 & 0.857 & 0.658 & \\
\hline 0.601 & 0.200 & 0.040 & 0.209 & 0.993 & 3.004 & \\
\hline 1.510 & 0.305 & 0.093 & 0.912 & 2.108 & 4.950 & \\
\hline 0.611 & 0.275 & 0.075 & 0.073 & 1.149 & 2.226 & \\
\hline 0.575 & 0.254 & 0.065 & 0.077 & 1.074 & 2.265 & \\
\hline 1.064 & 0.273 & 0.074 & 0.530 & 1.599 & 3.903 & \\
\hline 1.841 & 0.392 & 0.153 & 1.074 & 2.608 & 4.702 & \\
\hline 0.379 & 0.261 & 0.068 & -0.134 & 0.891 & 1.449 & \\
\hline 1.018 & 0.261 & 0.068 & 0.507 & 1.530 & 3.903 & \\
\hline 2.347 & 0.341 & 0.117 & 1.678 & 3.017 & 6.873 & \\
\hline 1.059 & 0.298 & 0.089 & 0.474 & 1.643 & 3.552 & \\
\hline 1.573 & 0.356 & 0.127 & 0.875 & 2.272 & 4.414 & \\
\hline 0.859 & 0.239 & 0.057 & 0.390 & 1.327 & 3.591 & \\
\hline 0.653 & 0.292 & 0.085 & 0.082 & 1.225 & 2.240 & \\
\hline 0.404 & 0.334 & 0.112 & -0.250 & 1.059 & 1.211 & \\
\hline 0.811 & 0.076 & 0.006 & 0.661 & 0.960 & 10.651 & \\
\hline
\end{tabular}

Hedges's $\mathrm{g}$ and $95 \% \mathrm{Cl}$
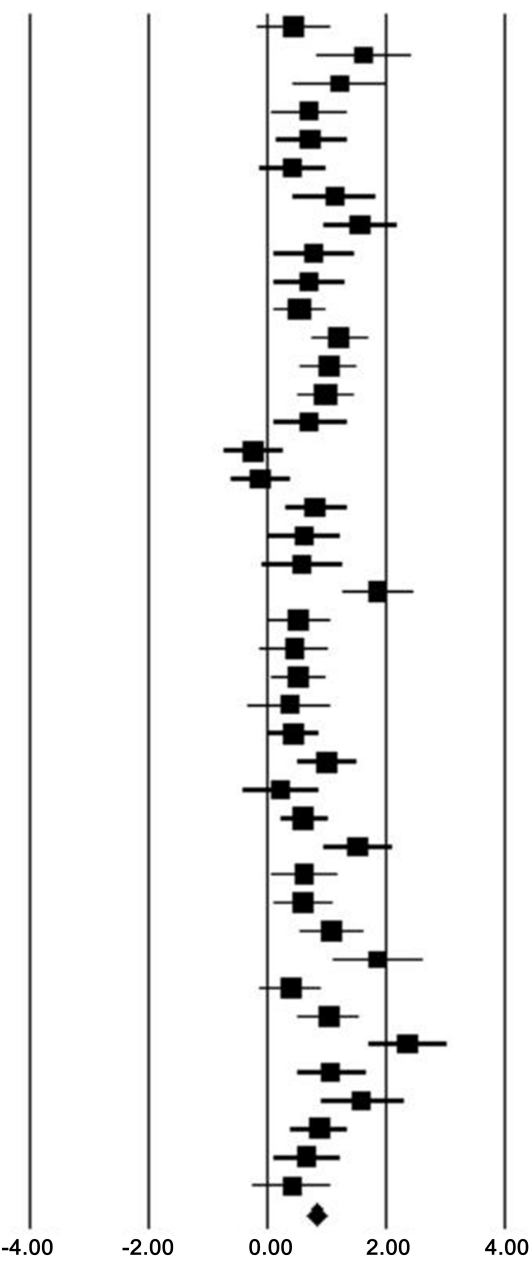

Favours B

Figure 3. Forest graph of the effect sizes of the studies in terms of random effects model 
Black squares in Figure 3 show effect sizes of individual studies and lines on both sides of squares show lower and upper limits of the effect size within $95 \%$ confidence interval. The surface of the squares points out the weight of the related study in overall effect size. The numerical values regarding the weight of individual studies are also given at the right side of Figure 3. Equilateral quadrangle below the squares presents the overall effect size of studies. When effect sizes are examined, it is seen that the lowest value is -0.232 while the highest value is 2.347 . 40 of calculated effect sizes are positive and 2 of them are negative. Consequently, the visualization technique implemented in 40 studies has an effect in favour of experimental group.

When primary studies included in meta-analysis are reviewed, it is seen that 8 studies have low level effect in terms of the effect of visualization on mathematics achievement $[1,4,31 \mathrm{~b}, 33,34,36,58,69]$, eighteen studies have medium level effects [2c, 3, 10, 14, 16a, 16d, 17, 20c, $27,28,31 \mathrm{a}, 32,35,37,49,50,65,68]$, fourteen studies have strong effects [2a, 2b, 5, 8, 16b, 16c, 29, 39, 51, 53, 59, 62, $63,64]$ and 2 studies have low level negative and weak effects [20a, 20b].

\subsection{Findings about the Effect Sizes in Terms of Educational Level}

Results regarding the calculated effect sizes in accordance with the effect of visualization on mathematics achievement in terms of educational level (middle school, high school, university) are given in Table 4.
The homogeneity value between the groups in terms of educational level was calculated as $\left(\mathrm{Q}_{B}\right) 0.056$. The critical value of the degree of freedom 2 at $95 \%$ significance level in Chi Square table is 5.991. It is seen that $\mathrm{Q}$ value is smaller than the corresponding critical value at degree of freedom 2 in Chi Square table $\left(\mathrm{Q}_{B}=0.056, \mathrm{p}=0.972\right)$. Thus, a statistically significant difference between the groups in terms of educational level cannot be found. According to Cohen et al. [15], effect sizes calculated in terms of education levels have a medium-level effect.

\subsection{Findings about the Effect Sizes in Terms of Implemented Visualization Technique}

Results regarding the calculated effect sizes in accordance with the implemented technique of visualization (computer-based, worksheet, paper folding-origami) to determine the effect of visualization on mathematics achievement are given in Table 5.

The homogeneity value between the groups in terms of implemented technique of visualization was calculated as $\left(Q_{B}\right) 0.816$. The critical value of the degree of freedom 2 at 95\% significance level in Chi Square table is 5.991. It is seen that $Q$ value is smaller than the corresponding value at degree of freedom 2 in Chi Square table $\left(\mathrm{Q}_{\mathrm{B}}=0.816\right.$, $\mathrm{p}=0.665$ ). Thus, a statistically significant difference between the groups in terms of implemented technique of visualization cannot be found. According to Cohen et al. [15], effect sizes calculated in terms of implemented technique of visualization have a medium-level effect.

Table 4. Effect size differences in terms of educational level

\begin{tabular}{|c|c|c|c|c|c|c|c|}
\hline \multirow{2}{*}{ Variable } & \multirow{2}{*}{$\begin{array}{l}\text { Homogeneity Value } \\
\text { Between Groups }\left(\mathrm{Q}_{\mathrm{B}}\right)\end{array}$} & \multirow{2}{*}{$\mathrm{p}$} & \multirow{2}{*}{$\mathrm{n}$} & \multirow{2}{*}{$\begin{array}{l}\text { Average Effect } \\
\text { Size Value (ES) }\end{array}$} & \multicolumn{2}{|c|}{ 95\% Confidence Interval for Effect Size } & \multirow{2}{*}{$\begin{array}{r}\text { Standard } \\
\text { Error (SE) }\end{array}$} \\
\hline & & & & & Lower Limit & Upper Limit & \\
\hline Educational Level & 0.056 & 0.972 & & & & & \\
\hline Middle School & & & 23 & 0.808 & 0.579 & 1.037 & 0.117 \\
\hline High School & & & 6 & 0.871 & 0.397 & 1.346 & 0.242 \\
\hline University & & & 12 & 0.823 & 0.607 & 1.039 & 0.110 \\
\hline
\end{tabular}

Table 5. Effect size differences in terms of implemented technique of visualization

\begin{tabular}{|c|c|c|c|c|c|c|c|}
\hline \multirow{2}{*}{ Variable } & \multirow{2}{*}{$\begin{array}{l}\text { Homogeneity Value } \\
\text { Between Groups }\left(\mathrm{Q}_{\mathrm{B}}\right)\end{array}$} & \multirow{2}{*}{$\mathrm{p}$} & \multirow{2}{*}{$\mathrm{n}$} & \multirow{2}{*}{$\begin{array}{l}\text { Average Effect } \\
\text { Size Value (ES) }\end{array}$} & \multicolumn{2}{|c|}{ 95\% Confidence Interval for Effect Size } & \multirow{2}{*}{$\begin{array}{l}\text { Standard } \\
\text { Error (SE) }\end{array}$} \\
\hline & & & & & Lower Limit & Upper Limit & \\
\hline \begin{tabular}{|c|} 
Implemented Technique of \\
Visualization \\
\end{tabular} & 0.816 & 0.665 & & & & & \\
\hline Computer-based & & & 35 & 0.826 & 0.649 & 1.004 & 0.091 \\
\hline Worksheet & & & 3 & 0.672 & 0.387 & 0.957 & 0.146 \\
\hline Paper Folding-Origami & & & 4 & 0.793 & 0.468 & 1.119 & 0.166 \\
\hline
\end{tabular}




\subsection{Findings about the Effects Sizes in Terms of Learning Domain}

Results regarding the calculated effect sizes in accordance with the learning domain (mathematics, geometry) to determine the effect of visualization on mathematics achievement are given in Table 6 .

The homogeneity value between the groups in terms learning domain was calculated as $\left(\mathrm{Q}_{B}\right)$ 0.662. The critical value of the degree of freedom 1 at $95 \%$ significance level in Chi Square table is 3.841. It is seen that $\mathrm{Q}$ value is smaller than the corresponding value at the degree of freedom 1 in Chi Square table $\left(\mathrm{Q}_{\mathrm{B}}=0.662, \mathrm{p}=0.416\right)$. Thus, a statistically significant difference between the groups in terms of learning domain cannot be found. According to Cohen et al. [15], effect sizes calculated in terms of field of education have medium-level effect.

\subsection{Findings about the Effect Sizes in Terms of Implementation Period}

Results regarding the calculated effect sizes in accordance with the implementation period (6-10 hours, 11-15 hours, 16-20 hours, 26-30 hours, unspecified) to determine the effect of visualization on mathematics achievement are given in Table 7.
When Table 7 is examined, it is seen that there is no study with 21-25 hours of implementation period and implementation period in 8 studies are not specified in hours. Therefore, the effect size for the implementation period of 21-25 hours could not be calculated. The homogeneity value between the groups in terms of implementation period was calculated as $\left(\mathrm{Q}_{\mathrm{B}}\right)$ 6.711. The critical value of the degree of freedom 4 at $95 \%$ significance level in Chi Square table is 9.488. It is seen that $\mathrm{Q}$ value is smaller than the corresponding value at the degree of freedom 4 in Chi Square table $\left(Q_{B}=6.711\right.$, $\mathrm{p}=0.152$ ). Thus, a statistically significant difference between the groups in terms of implementation period cannot be found. According to Cohen et al. [15], the effect size of implementation period of 16-20 hours has a large effect and the calculated effect sizes for implementation periods have medium-level effect.

\subsection{Findings about the Effect Sizes in Terms of Sample Size}

Results regarding the calculated effect sizes in accordance with sample size (21-40 participants, 41-60 participants, 61 participants and above) to determine the effect of visualization on mathematics achievement are given in Table 8.

Table 6. Effect size differences in terms of learning domain

\begin{tabular}{|c|c|c|c|c|c|c|c|}
\hline \multirow{2}{*}{ Variable } & \multirow{2}{*}{$\begin{array}{c}\text { Homogeneity Value } \\
\text { Between Groups }\left(\mathrm{Q}_{\mathrm{B}}\right)\end{array}$} & \multirow{2}{*}{$\mathrm{p}$} & \multirow{2}{*}{$\mathrm{n}$} & \multirow{2}{*}{$\begin{array}{l}\text { Average Effect } \\
\text { Size Value (ES) }\end{array}$} & \multicolumn{2}{|c|}{ 95\% Confidence Interval for Effect Size } & \multirow{2}{*}{$\begin{array}{c}\text { Standard } \\
\text { Error (SE) }\end{array}$} \\
\hline & & & & & Lower Limit & Upper Limit & \\
\hline Learning Domain & 0.662 & 0.416 & & & & & \\
\hline Mathematics & & & 15 & 0.753 & 0.611 & 0.895 & 0.072 \\
\hline Geometry & & & 27 & 0.863 & 0.640 & 1.085 & 0.114 \\
\hline
\end{tabular}

Table 7. Effect size differences in terms of implementation period

\begin{tabular}{|c|c|c|c|c|c|c|c|}
\hline \multirow{2}{*}{ Variable } & \multirow{2}{*}{$\begin{array}{l}\text { Homogeneity Value } \\
\text { Between Groups }\left(Q_{B}\right)\end{array}$} & \multirow{2}{*}{$\mathrm{p}$} & \multirow{2}{*}{$\mathrm{n}$} & \multirow{2}{*}{$\begin{array}{l}\text { Average Effect } \\
\text { Size Value (ES) }\end{array}$} & \multicolumn{2}{|c|}{ 95\% Confidence Interval for Effect Size } & \multirow{2}{*}{$\begin{array}{l}\text { Standard } \\
\text { Error }(\mathrm{SE})\end{array}$} \\
\hline & & & & & Lower Limit & Upper Limit & \\
\hline Implementation Period & 6.711 & 0.152 & & & & & \\
\hline 6-10 hours & & & 11 & 0.648 & 0.323 & 0.972 & 0.166 \\
\hline $11-15$ hours & & & 10 & 0.749 & 0.588 & 0.910 & 0.082 \\
\hline 16-20 hours & & & 4 & 1.251 & 0.843 & 1.660 & 0.209 \\
\hline 26-30 hours & & & 6 & 0.718 & 0.328 & 1.108 & 0.199 \\
\hline Unspecified & & & 8 & 0.996 & 0.513 & 1.478 & 0.246 \\
\hline
\end{tabular}

Table 8. Effect size differences in terms of sample size

\begin{tabular}{|c|c|c|c|c|c|c|c|}
\hline \multirow{2}{*}{ Variable } & \multirow{2}{*}{$\begin{array}{l}\text { Homogeneity Value } \\
\text { Between Groups }\left(\mathrm{Q}_{\mathrm{B}}\right)\end{array}$} & \multirow{2}{*}{$\mathrm{p}$} & \multirow{2}{*}{$\mathrm{n}$} & \multirow{2}{*}{$\begin{array}{l}\text { Average Effect } \\
\text { Size Value (ES) }\end{array}$} & \multicolumn{2}{|c|}{ 95\% Confidence Interval for Effect Size } & \multirow{2}{*}{$\begin{array}{c}\text { Standard } \\
\text { Error (SE) }\end{array}$} \\
\hline & & & & & Lower Limit & Upper Limit & \\
\hline Sample Size & 0.162 & 0.922 & & & & & \\
\hline 21-40 participants & & & 14 & 0.830 & 0.574 & 1.085 & 0.130 \\
\hline 41-60 participants & & & 17 & 0.823 & 0.512 & 1.133 & 0.159 \\
\hline 61 or more participants & & & 11 & 0.775 & 0.618 & 0.932 & 0.080 \\
\hline
\end{tabular}


When Table 8 is examined, it is seen that there is no study with a sample size of 1-20 participants. Therefore effect size of this group could not be calculated. The homogeneity value between the groups in terms of sample size was calculated as $\left(\mathrm{Q}_{\mathrm{B}}\right) 0.162$. The critical value of the degree of freedom 2 at $95 \%$ significance level in Chi Square table is 5.991. It is seen that Q value is smaller than the corresponding value at the degree of freedom 2 in Chi Square table $\left(\mathrm{Q}_{\mathrm{B}}=0.162, \mathrm{p}=0.922\right)$. Thus, a statistically significant difference between the groups in terms of sample size cannot be found. According to Cohen et al. [15], the effect sizes calculated in terms of sample size have medium-level effect.

\section{Discussions and Conclusions}

In this study, which examines the effect of visualization on mathematics achievement, 42 effect sizes related to individual studies were calculated. It is seen that 40 of these effect sizes have positive and 2 of them have negative values. The average effect size value of 42 studies calculated in accordance with random effect model is 0.811. According to Cohen et al. [15], this effect value is close to large. In this respect, it can be said that visualization in mathematics has a strong positive effect on the achievement. This result coincides with the studies which state that different visualization techniques used in mathematics instruction increase achievement [7, 18, 19, 38, 40, 56].

Regarding the studies included in meta-analysis educational level, implemented visualization technique, learning domain, implementation period and sample size were determined as moderator variables and their effect sizes were calculated.

In the study, educational level was divided into 3 groups such as middle school, high school and university and their effect values were calculated. In accordance with the effect values calculated in terms of educational level, no statistically significant difference was found between groups. The effect sizes calculated for these 3 groups have medium-level effects. It can be concluded that visualization has a similar positive effect in terms of educational levels.

The implemented techniques of visualization were divided into 3 groups; computer-based, worksheet and paper folding (origami) and the effect values of these groups were calculated. In accordance with the effect values calculated in terms of implemented techniques of visualization, no statistically significant difference was found between groups. The effect values calculated for these 3 groups have medium-level effect. It indicates that visualization has a similar positive effect in terms of implemented techniques of visualization.

The effect values with regard to 2 groups (mathematics and geometry) were calculated in terms of the learning domain. In accordance with the effect values calculated in terms of learning domain, no statistically significant difference was found between groups. The effect values calculated for these 2 groups have medium-level effect. However, it is seen that the effect value calculated for geometry is greater and close to a strong level effect. In this context, it can be said that the effect of visualization on achievement in geometry is greater than its effect on mathematics.

The implemented periods were divided into 5 groups 6-10 hours, 11-15 hours, 16-20 hours, 26-30 hours and unspecified and their effect values were calculated. No study was found related to 21-25 hours group in the study and the effect value of this group could not be calculated. In accordance with the effect values calculated in terms of the implementation period, no statistically significant difference was found between groups. However, it is seen that the effect value calculated for 16-20 hours group is at a strong level, the effect sizes with regard to 8 studies in which the implementation periods were not given in hours are close to strong level and other effect sizes have a medium-level effect.

Effects sizes of 3 groups were calculated in terms of sample size: 21-40 participants, 41-60 participants, 61 participants and more. Since there was no study regarding 1-20 participants group in terms of sample size, any effect value of this group could not be calculated. In accordance with the effect values calculated in terms of sample size, no statistically significant difference was found between groups. The effect sizes of these 3 groups have medium-level effects. This indicates that visualization has a similar positive effect in terms of sample size.

\section{Recommendation}

In this study, the effect of visualization in mathematics instruction was examined only in terms of achievement by using various variables. Therefore the effects of visualization on attitudes and motivation of students in mathematics instruction can also be investigated in terms of various variables.

As a consequence of the research, it is seen that visualization has a positive effect on mathematics achievement. Only 1 study done on the educational level of primary schools can be found among the theses in this topic. Therefore, it could be said that the studies investigating the effect of visualization on mathematics achievement for the preschool and primary school levels are needed.

In the study, it is seen that predominantly computer-based techniques are used as the implemented technique of visualization. Even so, it is also observed that computer-based techniques of visualization used in mathematics instruction do not make any significant differences in comparison with other techniques used. As a result, other techniques of visualization can be utilized in order to increase mathematics achievement in 
technologically insufficient environments.

\section{Notes}

An earlier version of this paper was presented at IV. International Eurasian Educational Congress, 11-14 May 2017, Pamukkale University, Turkey.

\section{REFERENCES}

An asterisk (*) mark with references indicates the studies included in this meta-analysis.

[1] *Ağaç, G. (2009). Lise öğrencilerinin trigonometri öğrenme alanında grafik hesap makinesi kullanımının akademik başarıya ve problem çözme becerisine etkisi (Unpublished master's thesis). Dokuz Eylül University, İzmir.

[2] *Akgül, A. (2014). Ortaokul 6, 7 ve 8. sinıflarda geometrik cisimlerin alan ve hacimlerinin öğretiminde Cabri $3 \mathrm{~d}$ yazılımının öğrenci başarısı ve tutumuna etkisi (Unpublished master's thesis). Firat University, Elazığ.

[3] *Aksoy, Y. (2007). Türev kavramının öğretiminde bilgisayar cebiri sistemlerinin etkisi (Unpublished doctoral dissertation). Gazi University, Ankara.

[4] *Aktümen, M. (2007). Belirli integral kavramının öğretiminde bilgisayar cebiri sistemlerinin etkisi (Unpublished doctoral dissertation). Gazi University, Ankara.

[5] *Andiç, T. (2012). İlköğretim 8. sınıf matematik dersi permütasyon kombinasyon konusunun bilgisayar destekli öğretiminin öğrenci erişi düzeylerine ve tutumlarına etkisi (Unpublished master's thesis). Yeditepe University, İstanbul.

[6] Arcavi, A. (2003). The role of visual representations in the learning of mathematics. Educational Studies in Mathematics, 52, 215-241.

[7] Ayvaz Reis, Z. ve Özdemir, Ş. (2010). Using Geogebra as an information technology tool: Parabola teaching. Procedia Social and Behavioral Sciences, 9, 565-572.

[8] *Balcı Şeker, H. (2014). Geogebra yazılımı ile geometri öğretiminin geometri ders başarısına ve geometri öz-yeterliğine etkisi (Unpublished master's thesis). Necmettin Erbakan University, Konya.

[9] Bardelle, C. (2010). Visual proofs: An experiment. Paper presented at the Proceedings of

the Sixth Congress of the European Society for Research in Mathematics

Education, Lyon, France.

[10] *Başaran Şimşek, E. (2012). Dinamik geometri yazılımı kullanmanın ilköğretim 6. sınıf öğrencilerinin matematik dersindeki akademik başarılarına ve uzamsal yeteneklerine etkisi (Unpublished master's thesis). Gazi University, Ankara.

[11] Bodzin, A. M. (2011). The implementation of a geospatial information technology (GIT)-supported land use change curriculum with urban middle school learners to promote spatial thinking. Journal of Research in Science Teaching, 48(3), 281-300.

[12] Borenstein, M., Hedges, L. V., Higgins, J. P. T., \& Rothstein, H. R. (2009). Introduction to meta-analysis. UK: John Wiley \& Sons, Ltd., Publications.

[13] Borwein, P., \& Jorgenson, L. (2001). Visible structures in number theory. The American Mathematical Monthly, 108(10), 897-1006.

[14] *Bulut, M. (2009). İșbirliğine dayalı yapılandırmac öğrenme ortamlarında kullanılan bilgisayar cebir sistemlerinin matematiksel düşünme, öğrenci başarısına ve tutumuna etkisi (Unpublished doctoral dissertation). Gazi University, Ankara.

[15] Cohen, L., Manion, L., \& Morrison, K. (2007). Research methods in education. New York: Routledge.

[16] *Çekmez, E. (2013). Dinamik matematik yazılımı kullanımının öğrencilerin türev kavramının geometrik boyutuna ilişkin anlamalarına etkisi (Unpublished doctoral dissertation). Karadeniz Teknik University, Trabzon.

[17] *Dağdelen, İ. (2012). İlköğretim geometri öğretiminde simetri kavramının origami ile modellenmesi (Unpublished master's thesis). Ondokuz May1s University, Samsun.

[18] DeLoach, M. (2013). The effect of graphing calculators on high school students' performance on a standardized mathematics test (Unpublished doctoral dissertation). University of Phoenix, Arizona, USA.

[19] DeMarinis, M. D. (2011). An interactive geometry program and its effect on elementary students' achievement and understanding of geometry: A comparative study (Unpublished doctoral dissertation). Columbia University, New York, USA.

[20] *Doktoroğlu, R. (2013). Dinamik matematik programı ile doğru denklemleri konusunun öğretiminin yedinci sınıf öğrencilerinin başarılarına etkileri (Unpublished master's thesis). Middle East Technical University, Ankara

[21] Ellis, P. D. (2010). The essential guide to effect sizes. Statistical power, meta-analysis, and the interpretation of research result. New York: Cambridge University Press.

[22] Farmaki, V., \& Paschos, T. (2007). The interaction between intuitive and formal mathematical thinking: A case study. International Journal of Mathematical Education in Science and Technology, 38(3), 353-365.

[23] Fennema, E., \& Romberg, T. A. (Eds.). (1999). Mathematics classrooms that promote understanding. Mahwah, New Jersey: Lawrence Erlbaum.

[24] Fraenkel, J. R., Wallen, N. E., \& Hyun, H. H. (2012). How to design and evaluate research in education. New York: McGraw-Hill.

[25] Glass, G. V. (1976). Primary, secondary, and meta-analysis of research. Educational Researcher, 5(10), 3-8.

[26] Gutiérrez, A. (1996). Visualization in 3-dimensional geometry: In search of a framework. Paper presented at the 20th International Group for the Psychology of Mathematics Education, Valencia, Spain. 
[27] *Gülbağc1, H. (2009). İlköğretim 7. sinıf dörtgenler konusunun öğretiminde dinamik geometri yazılımlarının etkisi (Unpublished master's thesis). Ankara University, Ankara.

[28] *Gülburnu, M. (2013). 8. sınıf geometri öğretiminde kullanılan Cabri 3d'nin akademik başarıya etkisi ve öğrenci görüşlerinin değerlendirilmesi (Unpublished master's thesis). Adıyaman University, Adıyaman.

[29] *Güneş, H. (2016). Analitik geometri öğretiminde Cabri 3d kullanımının öğretmen adaylarının akademik başarılarına etkisi ve görüsşlerinin değerlendirilmesi (Unpublished master's thesis). Uludağ University, Bursa.

[30] Hershkowitz, R. (1990). Psychological aspects of learning geometry. In P. Nesher, \& J. Kilpatrick (Eds.), Mathematics and cognition: A research synthesis by the International Group for the Psychology of Mathematics Education (pp. 70-95). Cambridge, MA: Cambridge University Press.

[31] *İbili, E. (2013). Geometri dersi için artırılmıș gerçeklik materyallerinin geliştirilmesi, uygulanması ve etkisinin değerlendirilmesi (Unpublished doctoral dissertation). Gazi University, Ankara.

[32] *İpek, A. S. (2003). Kompleks sayılarla ilgili kavramların anlaşılmasında görselleştirme yaklaşımının etkinliğinin incelenmesi (Unpublished doctoral dissertation). Atatürk University, Erzurum.

[33] *Kabaca, T. (2006). Limit kavramının öğretiminde bilgisayar cebiri sistemlerinin etkisi (Unpublished doctoral dissertation). Gazi University, Ankara.

[34] *Kalay, H. (2015). 7. sınıf öğrencilerinin uzamsal yönelim becerilerini geliştirmeye yönelik tasarlanan öğrenme ortamının değerlendirilmesi (Unpublished master's thesis). Karadeniz Teknik Üniversitesi, Trabzon.

[35] *Kan, O. (2014). Geogebra destekli öğretimin lineer cebir dersine ait bazı konularda akademik başarı üzerine etkisi (Unpublished master's thesis). Necmettin Erbakan University, Konya.

[36] *Karaaslan, G. (2013). Geometri dersine yönelik dinamik geometri yazılımlarıyla hazırlanan etkinliklerin öğrencilerin akademik başarısı ve uzamsal yetenekleri bağlamında incelenmesi (Unpublished master's thesis). Marmara University, İstanbul.

[37] *Konyalıoğlu, A. C. (2003). Üniversite düzeyinde vektör uzayları konusundaki kavramların anlaşılmasında görselleştirme yaklaşımının etkinliğinin incelenmesi (Unpublished doctoral dissertation). Atatürk University, Erzurum.

[38] Köklü, O. ve Topçu, A. (2012). Effect of Cabri-assisted instruction on secondary school students' misconceptions about graphs of quadratic functions. International Journal of Mathematical Education in Science and Technology, 43(8), 999-1011.

[39] *Küslü, F. (2015). Bilgisayar destekli matematik öğretiminin 8. sınıf öğrencilerinin prizmalar konusundaki başarısına etkisi (Unpublished master's thesis). Sakarya University, Sakarya.

[40] Lajinian, A. A. (2008). The effect of visually enhanced instructional units on high school calculus students' visualization ability and their understanding of the limit concept (Unpublished doctoral dissertation). Montclair State University, New Jersey, USA.

[41] Larkin, J., \& Simon, H. (1987). Why a diagram is (sometimes) worth ten thousand words. Cognitive Science, $11,65-100$.

[42] Mertens, D. M. (2010). Research and evaluation in education and psychology: Integrating diversity with quantitative, qualitative, and mixed methods. USA: Sage publications.

[43] Morgan, C. (2006). What does social semiotics have to offer mathematics education research? Educational Studies in Mathematics, 61, 219-245.

[44] Mullen, B., Muellerleile, P., \& Bryant, B. (2001). Cumulative meta-analysis: A consideration of indicators of sufficiency and stability. Personality and Social Psychology Bulletin, 27(11), 1450-1462.

[45] National Research Council. (2006). Learning to think spatially. Washington DC: National Academies Press.

[46] Nemirovsky, R., \& Noble, T. (1997). Mathematical visualization and the place where we live. Educational Studies in Mathematics, 33(2), 99-131.

[47] Neuman, W. L. (2013). Social research methods:Qualitative and quantitative approaches. USA: Pearson.

[48] Noss, R., Healy, L., \& Hoyles, C. (1997). The construction of mathematical meanings: Connecting the visual with the symbolic. Educational Studies in Mathematics, 33(2), 203-233.

[49] *Önür, Y. (2008). Grafiksel hesap makinelerinin doğrusal denklemlerin grafikleri ve eğim konusunda 8 . sinıf öğrencilerinin matematik başarısına etkisi (Unpublished master's thesis). Middle East Technical University, Ankara.

[50] *Özçakır Sümen, Ö. (2013). Geogebra yazılımı ile simetri konusunun ögretiminin matematik başarısı ve kaygısına etkisi (Unpublished master's thesis). Ondokuz Mayıs University, Samsun.

[51] *Özçelik, B. (2014). 6. sınıf matematik dersi geometri öğrenme alanında origami etkinliklerine yer verilmesinin öğrenci başarısına etkisi (Unpublished doctoral dissertation). Gazi University, Ankara.

[52] Rival, I. (1987). Picture puzzling: Mathematicians are rediscovering the power of pictorial reasoning. The Sciences, 27, 41-46.

[53] *Samur, H. (2015). Dinamik geometri kullanımının sekizinci sınıf öğrencilerinin üçgenler konusundaki geometri başarısına ve tutumuna etkisi (Unpublished master's thesis). Middle East Tecnical University, Ankara.

[54] Sánchez-Meca, J., \& Marín-Martínez, F. (2010). Meta analysis. In P. Peterson, E. Baker, \& B. McGaw (Eds.), International encyclopedia of education (Vol. 7, pp. 274-282). Oxford: Elsevier.

[55] Sinnett, S., Spence, C., \& Soto-Faraco, S. (2007). Visual dominance and attention: The colavita effect revisited. Perception \& Psychophysics, 69(5), 673-686.

[56] Steckroth, J. J. (2007). Technology-enhanced mathematics 
instruction: Effects of visualization on student understanding of trigonometry (Unpublished doctoral dissertation). University of Virginia, Virginia, USA.

[57] Stylianou, D. A., \& Silver, E. A. (2004). The role of visual representations in advanced mathematical problem solving: An examination of expert-novice similarities and differences. Mathematical Thinking and Learning, 6(4), 353-387.

[58] *Şimşek, M. (2012). Geometrik cisimler konusunun origami destekli etkinlikler ile öğretiminin başarıya etkisi (Unpublished master's thesis). Ondokuz Mayis University, Samsun.

[59] *Takıcak, M. (2012). Origami etkinliklerine dayalı öğretimin ilköğretim 8.sınıf öğrencilerinin üçgenler ünitesindeki akademik başarılarına ve geometriye yönelik tutumlarına etkisi (Unpublished master's thesis). Kastamonu University, Kastamonu.

[60] Tang, J. L., \& Liu, J. L. Y. (2000). Misleading funnel plot for detection of bias in meta-analysis. Journal of Clinical Epidemiology, 53(5), 477-484.

[61] Tappenden, J. (2005). Proof style and understanding in mathematics I: Visualization, unification and axiom choice. In P. Mancosu, K. F. Jørgensen, \& S. A. Pedersen (Eds.), Visualization, explanation and reasoning styles in mathematics (Synthese library) (Vol. 327, pp. 147-214). Dordrecht: Springer.

[62] *Tayan, E. (2011). Doğrusal denklemler ve grafikleri konusunun öğretiminde bilgisayar destekli öğretim yönteminin başarıya etkisi (Unpublished master's thesis). Atatürk University, Erzurum.

[63] *Tekin, B. (2010). Ortaöğretim düzeyinde trigonometri kavramlarının öğrenilmesinde görselleștirme yaklaşımının etkililiğinin araştırılması (Unpublished doctoral dissertation). Atatürk University, Erzurum.

[64] *Topaloğlu, İ. (2011). Cabri 3d ile yapılan ders tasarımlarının öğrencilerin uzamsal görselleme ve başarılarına etkisinin incelenmesi (Unpublished master's thesis). Marmara University, İstanbul.

[65] *Tural Sönmez, M. (2012). 6. sınıf matematik derslerinde web üzerinden sunulan eğitsel matematik oyunlarının öğrenci başarısına etkisi (Unpublished master's thesis). Çukurova University, Adana.

[66] Turğut, M. ve Yenilmez, K. (2012). Matematik öğretmeni adaylarının uzamsal görselleştirme becerileri. Eğitim ve Öğretim Araştırmaları Dergisi, 1(2), 243-252.

[67] Yavuz-Mumcu, H. ve Y1ld1z, S. (2015). Developing, implementing and evaluating of a web-based instructional material supporting spatial thinking. Elementary Education Online, 14(4), 1290-1306.

[68] *Yücesan, C. (2011). Bilgisayar destekli öğretimin 6. sınıf kümeler konusunda öğrenci başarısına etkisi (Unpublished master's thesis). Rize University, Rize.

[69] *Zengin, M. (2015). Autograph programı kullanımının 10. sınıf öğrencilerinin fonksiyonların simetrileri ve cebirsel özellikleri konusundaki başarısına etkisi (Unpublished master's thesis). Anadolu University, Eskişehir.

[70] Zimmerman, W., \& Cunningham, S. (1991). Editor's introduction: What is mathematical visualization? In W. Zimmerman, \& S. Cunningham (Eds.), Visualization in teaching and learning mathematics (pp. 1-8). Washington, DC: Mathematical Association of America, MAA Notes Series. 